\title{
Detection of Four Novel Polymorphisms in PrP gene of Pakistani sheep (Damani and Hashtnagri) and goats (Kamori and Local Hairy) breeds
}

\author{
Amjed Hussain ${ }^{1}$, Masroor E Babar ${ }^{2 *}$, Muhammad Imran³ ${ }^{3}$ Ikram U Haq ${ }^{1}$ and Muhammad M Javed
}

\begin{abstract}
Scrapie is a fatal neurodegenerative disorder of sheep and goats caused by post-translational conformational change in the host-encoded prion protein ( $\mathrm{PrP}^{\mathrm{C}}$ ). Susceptibility or resistance to scrapie has been associated with the presence of polymorphisms in the prion protein (PrP) gene. In the present study, we analyzed the PrP gene sequence to determine the frequency of polymorphisms in 56 sheep (28 each from Damani and Hashtnagri breeds) and 56 goats (28 each from Kamori and Local Hairy breeds). A total of 7 amino acid polymorphisms were detected in the PrP gene for sheep and 4 for goats. These amino acid polymorphisms were combined in 13 alleles and 15 genotypes in sheep and 5 alleles and 6 genotypes in goats. The overall frequency of the most sheep scrapie-resistant polymorphism (Q171R) was calculated to be 0.107 . The most scrapie-susceptible polymorphism (A136V) was not detected in any of the studied sheep. The overall frequency of scrapie-associated polymorphism $(\mathrm{H} 143 \mathrm{R})$ in goats was found to be 0.152 . Along with already known amino acid polymorphisms, two novel polymorphisms were also detected for each of sheep (Q171N and T191I) and goats (G22C and P63L). However, the overall frequency of these polymorphisms was extremely low.
\end{abstract}

\section{Introduction}

Scrapie in sheep and goats is the most ancient form among a group of chronic neurodegenerative disorders cumulatively known as prion diseases or transmissible spongiform encephalopathies (TSEs). TSEs other than scrapie include Cruetzfeldt-Jacob disease in humans, chronic wasting disease in deer and elk, mad cow disease in cattle and transmissible mink encephalopathy [1]. The unconventional etiology of TSEs is evidently associated with the conversion of a normal hostencoded prion protein $\left(\mathrm{PrP}^{\mathrm{C}-\text { Cellular }}\right)$ to abnormal pathogenic conformers $\left(\mathrm{PrP}^{\mathrm{Sc}-\mathrm{Scrapie}}\right)$ which get accumulated in the brain and lymphoid organs of cases in the form of fibrillar aggregates [2]. The detection of $\mathrm{PrP}^{\mathrm{Sc}}$ in relevant tissues is therefore regarded as the major diagnostic marker for the clinical evaluation of TSEs [3]. However, the sequence analysis of the $\operatorname{PrP}$ gene can also be used as a preliminary test to infer about the presence of a TSE [4]. The major concerns about TSEs are multiple

\footnotetext{
* Correspondence: drbabar@hotmail.com

${ }^{2}$ University of Veterinary and Animal Sciences, Lahore 54000, Pakistan

Full list of author information is available at the end of the article
}

$\operatorname{PrP}^{\mathrm{Sc}}$ strains causing variable long incubation periods depending on their infectious potential and the genetic makeup (species barrier) of the species involved [5,6] and the lack of suitable therapeutics $[7,8]$, which have paced up the prion research all over the world, especially in Europe and Northern America.

The key factors controlling the onset or incidence of TSEs are the PrP amino acid sequence and the expression level of the PrP gene. Therefore, the use of the PrP genetics has been suggested to control and eventually eradicate TSEs, especially animal TSEs. After the establishment of the genetic association of ovine and caprine PrP polymorphisms with natural or typical scrapie susceptibility and the disease progression, the study of the allele frequencies of the major PrP variants in sheep and goats has attained much attention worldwide and huge efforts have been made in this regard especially in Europe, USA, China and Japan. Several amino acid polymorphisms related to scrapie susceptibility have been reported for both sheep and goats [9]. Sheep exposed to natural or experimental $\operatorname{PrP}^{\mathrm{Sc}}$ infection have been shown to gain maximum scrapie resistance in the presence of Q171R polymorphism and maximum scrapie 
susceptibility in the presence of A136V polymorphism [10]. A three codon system based on A136V, R154H and Q171R/H polymorphisms has been characterized with five alleles (ARQ, VRQ, AHQ, ARR and ARH) which can be combined to form 15 genotypes i.e. ARR/ARR or VRQ/ARQ. These 15 genotypes have helped to develop a five-group risk classification system (R1-R5) which has been used in breeding and eradication programs $[11,12]$. The most resistant R1 genotype is ARR/ARR and the most susceptible R5 genotypes are VRQ/VRQ, VRQ/ ARQ, VRQ/ARH and VRQ/AHQ. Though ovine PrP polymorphism has been abundantly linked to the scrapie risk, a few studies have been carried out for the analysis of caprine PrP gene in this regard. This is due to the fact that the prevalence of typical scrapie outbreaks in goat is comparatively much lower than in sheep. However, caprine $\operatorname{PrP}$ polymorphisms I142M, H143R, N146S/D, R154H, R211Q and Q222K have been shown to be associated with resistance or low scrapie risk [13-18] and are therefore being studied worldwide [19,20]. Many other ovine and caprine PrP polymorphisms have also been reported, which can be reviewed in [9,20-23].

Sheep and goats are major livestock species of Pakistan contributing almost $33 \%$ of the total red meat consumed in the country. These species also provide the basic economic source for many people dwelling in the underdeveloped parts of the country. The present study was conducted for the sequence analysis of coding sequences of the PrP gene in two each of Pakistani sheep (Damani and Hashtnagri) and goats (Kamori and Local Hairy) breeds. Although no scrapie case has been reported in any of Pakistani sheep and goats, knowing the PrP gene polymorphism spectrum in these species may be helpful for future breeding plans in terms of scrapie resistance.

\section{Materials and Methods}

The study was approved by Ethical Review Committee of University of Veterinary and Animal Sciences Lahore. Twenty-eight animals from each of two sheep (Damani and Hashtnagri) and two goats (Kamori and Local Hairy) breeds were selected for blood sampling from their respective breeding tracts and Government Livestock Farms. Kamori was sampled from Sindh, Local Hairy from Punjab, and Damani and Hashtnagri from Khyber Pakhtunkhwa. The selection of more than one animal from the same pedigree was avoided to increase the genetic heterogeneity among the samples. The genetic heterogeneity was further increased by selecting only a few unrelated animals from a flock. Ten ml blood samples of selected animals were collected from their jugular vein into $50 \mathrm{ml}$ falcon tubes, containing $100 \mu \mathrm{l}$ of $0.5 \mathrm{M}$ EDTA ( $\mathrm{pH}$ 8.0), and immediately transferred to an ice box and stored at $-20^{\circ} \mathrm{C}$ until further processing.
Extraction of genomic DNA from whole blood was performed by inorganic procedure [24]. A DNA fragment of 876 bp length containing the entire coding region in exon 3 of the PrP gene (GeneBank accession, DQ346682), was PCR-amplified by using a primer pair (F5'-1CTTTAAGTGATTTTTACGTGG21-3') and (R5'854TGGCAAAGATTAAGAAGATAATG876-3'). PCR reactions were carried out in a total volume of $25 \mu \mathrm{l}$ containing 50 ng genomic DNA, $10 \mathrm{mM}$ Tris/ $\mathrm{HCl}(\mathrm{pH} 8.3)$, $50 \mathrm{mM} \mathrm{KCl}, 1.5 \mathrm{mM} \mathrm{MgCl}$, $200 \mu \mathrm{M}$ dNTPs, 10 pmoles of each primer and $1.5 \mathrm{U}$ Taq polymerase (Fermentas Inc. USA). Thermal program of PCR was set as initial denaturation at $94^{\circ} \mathrm{C}$ for $4 \mathrm{~min}$, followed by 35 cycles of denaturation at $94^{\circ} \mathrm{C}$ for $45 \mathrm{~s}$, annealing at $54^{\circ} \mathrm{C}$ for $45 \mathrm{~s}$ and extension at $72^{\circ} \mathrm{C}$ for $1 \mathrm{~min}$. A final $10 \mathrm{~min}$ extension at $72^{\circ} \mathrm{C}$ was also added to the program. The PCR products were purified by $64 \%$ ethanol at final concentration and were used in dideoxy sequencing reactions. Additional to above-mentioned primer pair, PrP7-U (5'369AGCAGTGGTAGGGGGCCTTGGT391- 3') and PrP-L2 (5' - 430TTTGGCTTACTGGGCTTGTTCC451- 3') primes were also used in sequencing PCR reactions for bidirectional sequencing of the entire coding region of the PrP gene. The amplified products of sequencing PCR were purified using $70 \%$ ethanol and resolved on an $\mathrm{ABI}$ 3130 capillary DNA analyzer (Applied Biosystems, Inc., Foster City, CA). The PrP gene sequences were visually inspected using the Chromas Lite (2.01) software and then transported to BLAST for their alignment with the standard sequence.

\section{Results}

Sequencing of the PrP gene showed seven amino acid polymorphisms in two sheep breeds (Damani and Hashtnagri) and four in two goat breeds (Kamori and Local Hairy) of Pakistan (Table 1). These amino acid polymorphisms were combined in 13 alleles and 15 genotypes in sheep and 5 alleles and 6 genotypes in goats. The maximally detected allele in sheep with an overall frequency of 0.500 was of wild-type $\left(\mathrm{G}_{127} \mathrm{R}_{151} \mathrm{Y}_{152} \mathrm{Q}_{171} \mathrm{Q}_{189} \mathrm{~T}_{191}\right)$. The $\mathrm{G}_{127} \mathrm{R}_{151} \mathrm{Y}_{152} \mathrm{Q}_{171} \mathrm{~L}_{189} \mathrm{~T}_{191}$ allele was the second frequent allele in sheep with an overall frequency of 0.116 . Ultimately the genotypes with these two alleles were detected with higher frequency. Two alleles $G_{127} R_{151} Y_{152} N_{171} Q_{189} T_{191}$ and $\left.G_{127} R_{151} Y_{152} Q_{171} Q_{189} I_{191}\right)$ carried the new amino acid polymorphisms Q171N (cag171aat) and T191I (aca191ata). These alleles were found only once (heterozygous- 1/56 = 0.009 ) in two different sheep. Additionally, two previously reported silent mutations (agg231cgg - R231R and ctc237ctg - L237L) were also detected in six animals.

In goats, $\mathrm{G}_{22} \mathrm{P}_{63} \mathrm{H}_{143} \mathrm{P}_{240}$ allele was maximally found with an overall frequency of 0.527 , followed by the wildtype allele $\mathrm{G}_{22} \mathrm{P}_{63} \mathrm{H}_{143} \mathrm{~S}_{240}$ that represented $30.4 \%$ of the alleles (Table 1). The maximally detected genotype was 
Table 1 Allelic and genotypic frequencies of PrP in Damani and Hashtnagri, and Kamori and Local Hairy

\begin{tabular}{|c|c|c|c|c|c|c|c|c|}
\hline & \multicolumn{8}{|l|}{ Allelic frequencies } \\
\hline & & \multicolumn{3}{|c|}{ Sheep breeds } & & \multicolumn{3}{|c|}{ Goat breeds } \\
\hline & & \multicolumn{2}{|c|}{ Damani Hashtnagri } & \multirow{2}{*}{$\begin{array}{l}\text { Both } \\
n / 112\end{array}$} & & \multirow{2}{*}{$\begin{array}{l}\text { Kamori } \\
\mathrm{n} / 56\end{array}$} & \multirow{2}{*}{$\begin{array}{l}\text { Local Hairy } \\
\mathrm{n} / 56\end{array}$} & \multirow{2}{*}{$\begin{array}{l}\text { Both } \\
n / 112\end{array}$} \\
\hline & & $n / 56$ & $n / 56$ & & & & & \\
\hline 1 & $\mathrm{G}_{127} \mathrm{R}_{151} \mathrm{Y}_{152} \mathrm{Q}_{171} \mathrm{Q}_{189} \mathrm{~T}_{191}$ & 0.464 & 0.536 & 0.500 & $\mathrm{G}_{22} \mathrm{P}_{63} \mathrm{H}_{143} \mathrm{~S}_{240}$ & 0.232 & 0.375 & 0.304 \\
\hline 2 & SRYQQT & 0.054 & 0.161 & 0.107 & GPHP & 0.589 & 0.464 & 0.527 \\
\hline 3 & $\underline{\text { SRYRQT }}$ & 0.018 & 0.000 & 0.009 & CPHP & 0.018 & 0.000 & 0.009 \\
\hline 4 & $\overline{\mathrm{SRYHQT}}$ & 0.018 & 0.036 & 0.027 & GLHP & 0.018 & 0.000 & 0.009 \\
\hline 5 & SRYQLT & 0.018 & 0.018 & 0.018 & GPRP & 0.143 & 0.161 & 0.152 \\
\hline 6 & GCYQQT & 0.036 & 0.018 & 0.027 & & & & \\
\hline 7 & GRPQQT & 0.018 & 0.018 & 0.018 & & & & \\
\hline 8 & GRYQQI & 0.000 & 0.018 & 0.009 & & & & \\
\hline 9 & GRYRQT & 0.161 & 0.036 & 0.098 & & & & \\
\hline 10 & GRYHQT & 0.000 & 0.018 & 0.009 & & & & \\
\hline 11 & $\overline{\text { GRYNQT }}$ & 0.000 & 0.018 & 0.009 & & & & \\
\hline 12 & GRYKQT & 0.071 & 0.036 & 0.054 & & & & \\
\hline \multirow[t]{3}{*}{13} & GRYQLT & 0.143 & 0.089 & 0.116 & & & & \\
\hline & Genotypic frequencies & & & & & & & \\
\hline & & $n / 28$ & $n / 28$ & $n / 56$ & $n / 28$ & $n / 28$ & $n / 56$ & \\
\hline 1 & GRYQQT/GRYQQT & 0.357 & 0.464 & 0.411 & GPHS/GPHS & 0.107 & 0.286 & 0.196 \\
\hline 2 & SRYQQT/SRYQQT & 0.00 & 0.107 & 0.054 & GPHS/GPHP & 0.250 & 0.179 & 0.214 \\
\hline 3 & $\underline{\text { SRYQQT/SRYRQT }}$ & 0.036 & 0.00 & 0.018 & GPHP/GPHP & 0.286 & 0.214 & 0.250 \\
\hline 4 & SRYQQT/SRYHQT & 0.036 & 0.071 & 0.054 & CPHP/GPHP & 0.036 & 0.00 & 0.018 \\
\hline 5 & SRYQQT/SRYQLT & 0.036 & 0.036 & 0.036 & GLHP/GPHP & 0.036 & 0.00 & 0.018 \\
\hline 6 & GRYQQT/GCYQQ & 0.071 & 0.036 & 0.054 & GPRP/GPHP & 0.286 & 0.32 & 0.304 \\
\hline 7 & GRPQQT/GRYKQ & 0.036 & 0.036 & 0.036 & & & & \\
\hline 8 & GRYQQT/GRYQQI & 0.00 & 0.036 & 0.018 & & & & \\
\hline 9 & $\underline{\text { GRYQQT/GRYRQT }}$ & 0.107 & 0.036 & 0.071 & & & & \\
\hline 10 & $\overline{\text { GRYRQT/GRYRQT }}$ & 0.071 & 0.000 & 0.036 & & & & \\
\hline 11 & $\overline{\mathrm{GRYRQT} / \mathrm{GRYQLT}}$ & 0.071 & 0.036 & 0.054 & & & & \\
\hline 12 & GRYHQT/GRYNQT & 0.000 & 0.036 & 0.018 & & & & \\
\hline 13 & $\overline{\text { GRYKQT/GRYQLT }}$ & 0.071 & 0.00 & 0.036 & & & & \\
\hline 14 & GRYQQT/GRYKQT & 0.036 & 0.036 & 0.036 & & & & \\
\hline 15 & GRYQLT/GRYQLT & 0.071 & 0.071 & 0.071 & & & & \\
\hline
\end{tabular}

Alleles and genotypes associated with susceptibility/resistance to scrapie are underlined.

$\mathrm{G}_{22} \mathrm{P}_{63} \mathrm{R}_{143} \mathrm{P}_{240} / \mathrm{G}_{22} \mathrm{P}_{63} \mathrm{H}_{143} \mathrm{P}_{240}$ (0.304) followed by $\mathrm{G}_{22} \mathrm{P}_{63} \mathrm{H}_{143} \mathrm{P}_{240} / \mathrm{G}_{22} \mathrm{P}_{63} \mathrm{H}_{143} \mathrm{P}_{240}$ (0.250). Two alleles $\mathrm{C}_{22} \mathrm{P}_{63} \mathrm{H}_{143} \mathrm{P}_{240}$ and $\mathrm{G}_{22} \mathrm{~L}_{63} \mathrm{H}_{143} \mathrm{P}_{240}$ carried the new amino acid polymorphisms G22C (ggc22tgc) and P63L (ccc63ctc). Both G22C and P63L were detected in heterozygous state. The three amino acid polymorphisms (22C, 63L and 143R) were found linked with 240P. Three previously known silent mutations (ccg42cca P42P, ggc83gga - G83G and agc138agt - S138S) were also detected. Both $42 \mathrm{a}$ and $138 \mathrm{t}$ were linked with $240 \mathrm{P}$ in most of animals. A few goats with linkage of $42 \mathrm{~g}$ or $138 \mathrm{c}$ with $240 \mathrm{~S}$ were also found.

\section{Discussion}

The European sheep and goat husbandry has suffered huge economic losses due to scrapie outbreaks. Scrapie like other prion diseases has equal chance of being transmitted within and among species, depending on the PrP gene sequence $[5,6]$. The advent of modern gene sequence technologies have now paved the path for breeders to make sheep and goats resistant against upsetting disorders including scrapie by helping them in determining the allele frequencies, which is a prerequisite to devise an appropriate breeding plan.

Resistance to natural or experimental $\operatorname{PrP}^{\mathrm{Sc}}$ in sheep scrapie is reported to be controlled by M112T, A136V, M137T, I142K, R154H, P168L, Q171R/H and N176K polymorphisms of the PrP gene [10,11,25-30]. However, only A136V, R154H and Q171R/H have been targeted for selective breeding against scrapie susceptibility based on their accepted involvement in the modulation of resistance to the disease [9]. The PrP gene carrying 
Q171R polymorphism confers the highest resistance to sheep scrapie. Conversely, the presence of A136V polymorphism in the PrP gene makes sheep highly susceptible to the disease. In the present study, no sheep was found carrying the A136V polymorphism. This polymorphism has also not been detected in our previous studies involving nine Pakistani sheep breeds [31,32]. Moreover, F141L that is a risk factor for atypical scrapie [33] was absent from the PrP gene of the studied sheep. $\mathrm{R} 154 \mathrm{H}$ that is another risk factor for atypical scrapie $[33,34]$ but is known to confer resistance to typical scrapie in both sheep and goats $[10,18]$, was also not detected for the studied sheep and goats. Except Q171R/H, no other polymorphism associated with sheep scrapie was detected for Damani and Hashtnagri (Table $1)$. But the same as in our previous studies [33,34], its frequency $(0.107)$ is lower raising the scrapie risk in the studied sheep breeds.

Amongst caprine PrP polymorphisms I142M, H143R, N146S/D, R154H, R211Q and Q222K associated with resistance to scrapie [13-18], only H143R was detected for the studied goats. This polymorphism has also been detected in other Pakistani goat breeds like Pak Angora, Teddy and Beetal [35]. Like sheep, the lower frequency of H143R may raise the scrapie risk in the studied goat breeds. The only polymorphism that is common in goats both from Pakistan $[35,36]$ as well as other countries of the world [23] is S240P. As was the case in this study, this polymorphism is often found linked with other amino acid polymorphisms in the caprine PrP gene [9].

Due to species barrier conferred by sequence variation, the rare polymorphisms in the PrP gene may also be useful in protecting animals against $\mathrm{PrP}^{\mathrm{Sc}}$ infection. In the present study, two new and rare PrP polymorphisms were detected in each of sheep (Q171N and T191I, accession \# GQ497224 and GQ497223, respectively) and goats (G22C and P63L, accession \# GQ497228 and GQ497222, respectively) (Table 1).

\section{Acknowledgements}

We thank Dr. Tanveer Hussain, University of Veterinary and Animal Sciences Lahore, Pakistan for his help in blood sampling.

\section{Author details}

${ }^{1}$ Government College University, Lahore 54000, Pakistan. ${ }^{2}$ University of Veterinary and Animal Sciences, Lahore 54000, Pakistan. ${ }^{3}$ Centre for Research in Endocrinology and Reproductive Sciences, University of Health Sciences (UHS), Khayaban-e-Jamia Punjab, Lahore 54600, Pakistan.

\section{Authors' contributions}

$\mathrm{AH}$ carried out experiments, performed sequence alignments and participated in writing the manuscript and data analysis. MEB conceived, designed and supervised the study. $\mathrm{Ml}$ analyzed the data and wrote the manuscript. IUH and MMJ coordinated the study. All authors read and approved the manuscript.

\section{Competing interests}

The authors declare that they have no competing interests.

Received: 17 February 2011 Accepted: 20 May 2011

Published: 20 May 2011

\section{References}

1. Belay ED: Transmissible spongiform encephalopathies in humans. Ann Rev Microbiol 1999, 53:283-314.

2. Prusiner SB: Prion biology and diseases. Cold Spring Harbor Laboratory Press. Cold Spring Harbor, NY; 2004.

3. Peden $\mathrm{AH}$, Head MW, Jones M, MacGregor I, Turner M, Ironside J: Advances in the development of a screening test for variant Creutzfeldt-Jakob disease. Expert Opin Med Diag 2008, 2(2):207-219.

4. Wadsworth JD, Powell C, Beck JA, Joiner S, Linehan JM, Brandner S, Mead S, Collinge J: Molecular diagnosis of human prion disease. Methods Mol Biol 2008, 459:197-227.

5. Béringur V, Vilotte Jean-Luc, Laude H: Prion agent diversity and species barrier. Vet Res 2008, 39:47.

6. Collinge J, Clarke AR: A general model of prion strains and their pathogenecity. Science 2007, 318(5852):930-936.

7. Stewart LA, Rydzewska LH, Keogh GF, Knight RS: Systematic review of therapeutic interventions in human prion disease. Neurology 2008, 70(15):1272-1281.

8. Ludewigs H, Zuber C, Vana K, Nikles D, Zerr I, Weiss S: Therapuetic approaches for prion disorders. Expert Rev Anti Infect Ther 2007, 5(4):613-630.

9. Goldmann W: PrP genetics in ruminant transmissible spongiform Encephalopathies. Vet Res 2008, 39:30.

10. Baylis M, Goldmann W: The genetics of scrapie in sheep and goats. Curr Mol Med 2004, 4:385-396.

11. Dawson $M$, Hoinville $L$, Hosie $B D$, Hunter $N$ : Guidance on the use of $\operatorname{Pr} P$ genotyping as an aid to the control of clinical scrapie. Vet Rec 1998 23:623-625.

12. Detweiler LA, Baylis M: The epidemiology of scrapie. Rev -Off Int Epizoot 2003, 22:121-143.

13. Goldmann W, Martin T, Foster J, Hughes S, Smith G, Hughes K, Dawson M, Hunter N: Novel polymorphisms in the caprine PrP gene: a codon 142 mutation associated with scrapie incubation period. J Gen Virol 1996, 77:2885-2891.

14. Billinis C, Panagiotidis CH, Psychas V, Argyroudis S, Nicolaou A, Leontides S, Papadopoulos O, Sklaviadis T: Prion protein gene polymorphisms in natural goat scrapie. J Gen Virol 2002, 83:713-721.

15. Acutis PL, Bossers A, Priem J, Riina MV, Peletto S, Mazza M, Casalone C, Forloni G, Ru G, Caramelli M: Identification of prion protein gene polymorphisms in goats from Italian scrapie outbreaks. J Gen Virol 2006, 87:1029-1033.

16. Vaccari G, Di Bari MA, Morelli L, Nonno R, Chiappini B, Antonucci G, Marcon S, Esposito E, Fazzi P, Palazzini N, Troiano P, Petrella A, Di Guardo G, Agrimi U: Identification of an allelic variant of the goat PrP gene associated with resistance to scrapie. J Gen Virol 2006, 87:1395-1402.

17. Papasavva-Stylianou P, Kleanthous M, Toumazos P, Mavrikiou P, Loucaides P. Novel polymorphisms at codons 146 and 151 in the prion protein gene of Cyprus goats, and their association with natural scrapie. Vet J 2007, 173:459-462.

18. Barillet F, Mariat D, Amigues $Y$, Faugeras R, Caillat H, Moazami-Goudarzi K, Rupp R, Babilliot JM, Lacroux C, Lugan S, Schelcher F, Chartier C, Corbière F, Andréoletti $\mathrm{O}$, Perrin-Chauvineau C: Identification of seven haplotypes of the caprine PrP gene at codons 127, 142, 154, 211, 222 and 240 in French Alpine and Saanen breeds and their association with classical scrapie. J Gen Virol 2009, 90(Pt 3):769-776.

19. Kurosaki $Y$, Ishiguro N, Horiuchi M, Shinagawa M: Polymorphisms of caprine PrP gene detected in Japan. J Vet Med Sci 2005, 67:321-323.

20. Zhou RY, Li XL, Li LH, Wang HY, Lü JG: Polymorphism of the PRNP gene in the main breeds of indigenous Chinese goats. Arch Virol 2008, 153(5):979-982.

21. Acutis PL, Colussi S, Santagada G, Laurenza C, Maniaci MG, Riina MV, Peletto S, Goldmann W, Bossers A, Caramelli M, Cristoferi I, Maione S, Sacchi P, Rasero R: Genetic variability of the PRNP gene in goat breeds from Northern and Southern Italy. J Appl Microbiol 2008, 104(6):1782-1789. 
22. Wang Y, Qin Z, Qiao J, Zhao D: Polymorphisms of the prion protein gene in sheep of Inner Mongolia, China. Virus Genes 2008, 37(1):128-130.

23. Serrano C, Hammouchi M, Benomar A, Lyahyai J, Ranera B, Acı'n C, el Hamidi M, Monzo'n M, Badiola JJ, Tligui N, Zaragoza P, Martı'n-Burriel I: PRNP haplotype distribution in Moroccan goats. 2009.

24. Grimberg J, Nawoschik S, Belluscio L, Mckee R, Turk A, Eiswenberg A: A simple and efficient non-organic procedure for the isolation of genomic DNA from blood. Nucl Acids Res 1989, 17:8390.

25. Yang S, Thackray AM, Fitzmaurice TJ, Bujdoso R: Copper-induced structural changes in the ovine prion protein are influenced by a polymorphism at codon 112. Biochim Biophys Acta 2008, 1784(4):683-692.

26. Laegreid WW, Clawson ML, Heaton MP, Green BT, O'Rourke KI, Knowles DP: Scrapie resistance in ARQ sheep. J Virol 2008, 82(20):10318-10320.

27. Vaccari G, D'Agostino C, Nonno R, Rosone F, Conte M, Di Bari MA, Chiappini B, Esposito E, De Grossi L, Giordani F, Marcon S, Morelli L, Borroni R, Agrimi U: Prion protein alleles showing a protective effect on the susceptibility of sheep to scrapie and bovine spongiform encephalopathy. J Virol 2007, 81(13):7306-7309.

28. Vaccari G, D'Agostino C, Nonno R, Rosone F, Conte M, Di Bari MA, Chiappini B, Esposito E, De Grossi L, Giordani F, Marcon S, Morelli L, Borroni R, Agrimi U: Prion protein alleles showing a protective effects on the susceptibility of sheep to scrapie and bovine spongiform encephalopathy. J Virol 2007, 81(13):7306-7309.

29. Vaccari G, Scavia G, Sala M, Cosseddu G, Chiappini B, Conte M, Esposito E, Lorenzetti R, Perfetti G, Marconi P, Scholl F, Barbaro K, Bella A, Nonno R, Agrimi U: Protective effect of the AT137RQ and ARQK176 PrP alleles against classical scrapie in Sarda breed sheep. Vet Res 2009, 40:19.

30. Goldmann W, Houston F, Stewart P, Perucchini M, Foster J, Hunter N: Ovine prion protein variant A136R154L168Q171 increases resistance to experimental challenge with bovine spongiform encephalopathy agent. $J$ Gen Virol 2006, 87:3741-3745.

31. Babar ME, Farid A, Benkel BF, Ahmad J, Sajid IA, Imran M, Hussain T, Nadeem A: Genetic variability at seven codons of the prion protein gene in nine Pakistani sheep breeds. J Genet 2008, 87(2):187-190.

32. Babar ME, Farid A, Benkel BF, Ahmad J, Nadeem A, Imran M: Frequencies of PrP genotypes and their implication for breeding against scrapie susceptibility in nine Pakistani sheep breeds. Mol Biol Rep 2009, 36(3):561-565.

33. Moum T, Olsaker I, Hopp P, Moldal T, Valheim M, Moum T, Benestad SL: Polymorphisms at codons 141 and 154 in the ovine prion protein gene are associated with scrapie Nor98 cases. J Gen Virol 2005, 86:231-235.

34. Colussi S, Vaccari G, Maurella C, Bona C, Lorenzetti R, Troiano P, Casalinuovo F, Di Sarno A, Maniaci MG, Zuccon F, Nonno R, Casalone C, Mazza M, Ru G, Caramelli M, Agrimi U, Acutis PL: Histidine at codon 154 of the prion protein gene is a risk factor for Nor98 scrapie in goats. $J$ Gen Virol 2008, 89(Pt 12):3173-3176.

35. Babar ME, Nawaz M, Nasim A, Abdullah M, Imran M, Jabeen R, Chatha SA, Haq AU, Nawaz A, Mustafa H, Nadeem A: Prion protein genotypes in Pakistani goats. Asian-Aust J Anim Sci 2008, 21(7):936-940.

36. Babar ME, Abdullah M, Nadeem A, Haq AU: Prion protein gene polymorphisms in four goat breeds of Pakistan. Mol Biol Rep 2009, 36(1):141-144.

\section{doi:10.1186/1743-422X-8-246}

Cite this article as: Hussain et al:: Detection of Four Novel

Polymorphisms in PrP gene of Pakistani sheep (Damani and Hashtnagri) and goats (Kamori and Local Hairy) breeds. Virology Journal 2011 8:246.

\section{Submit your next manuscript to BioMed Central and take full advantage of:}

- Convenient online submission

- Thorough peer review

- No space constraints or color figure charges

- Immediate publication on acceptance

- Inclusion in PubMed, CAS, Scopus and Google Scholar

- Research which is freely available for redistribution 